\title{
Intravenous paracetamol and intraocular pressure reduction: mannitol may also be involved
}

\author{
This article was published in the following Dove Press journal: \\ Clinical Ophthalmology \\ 15 September 2016 \\ Number of times this article has been viewed
}

\author{
Karel Allegaert ${ }^{1,2}$ \\ 'Intensive Care, Department \\ of Surgery, Erasmus MC Sophia \\ Children's Hospital, Rotterdam, \\ the Netherlands; ${ }^{2}$ Department of \\ Development and Regeneration, \\ KU Leuven, Belgium
}

Correspondence: Karel Allegaert Neonatal Intensive Care Unit, University Hospital, Herestraat 49, 3000 Leuven, Belgium

$\mathrm{Tel}+32$ I6 343850

Fax +32 16343209

Email karel.allegaert@uzleuven.be

\section{Dear editor}

I read, with great interest, the paper on the intraocular pressure-lowering properties of intravenous paracetamol (acetaminophen) recently published in this journal by van den Heever and Meyer. ${ }^{1}$ The authors documented a decrease from baseline in mean intraocular pressure of $15.7 \%$ in a 6-hour time interval following intravenous paracetamol (1 g Perfalgan ${ }^{\circledR}$, Bristol-Myers Squibb, New York, NY, USA) administration. This mean decrease was moderate but relevant when compared to, for example, topical timolol $(-25.3 \%$, single drop $0.5 \%$ timolol maleate) or oral acetazolamide $(-23.1 \%, 250 \mathrm{mg})$. Although the authors provided potential relevant mechanistic arguments in support of a link between paracetamol administration and intraocular pressure through the endocannabinoid system, we would like to draw attention to the fact that - when intravenous paracetamol is administered - a relevant amount of mannitol is coadministered.

Clinicians and clinical researchers should be aware that drug formulations commonly contain excipient(s) besides the active compound(s). This is also true for Perfalgan ${ }^{\circledR}$ that contains $\sim 3.9 \mathrm{~g}$ of mannitol (in $1 \mathrm{~g}$ paracetamol in a $100 \mathrm{~mL}$ vial). ${ }^{2}$ I suggest that at least part of the effects observed may relate to the excipient, mannitol. Although recommendations do vary, mannitol doses of $0.25-2 \mathrm{~g} / \mathrm{kg}$ over $30-60$ minutes have been suggested to reduce intraocular pressure; while the paracetamol formulation results in coadministration of mannitol $(3.9 \mathrm{~g}=0.055 \mathrm{~g} / \mathrm{kg}$ over 15 minutes). To further illustrate this, $12 \mathrm{~g}$ of intravenous mannitol resulted in a drop in intraocular pressures with a subsequent return to baseline by 2 hours in 38 eyes of 19 subjects. ${ }^{3}$

Understanding the mechanism(s) involved in the reduction in intraocular pressure matters and goes beyond academic reflections. First, not all currently marketed intravenous paracetamol formulations contain mannitol. ${ }^{2}$ This means that the clinical message of the paper to consider recent exposure to intravenous paracetamol when interpreting ocular pressure measurement should be considered carefully until the mannitol effect has been disentangled from the paracetamol effect. Similarly, initiating acute or chronic exposure to paracetamol (either systemic through intravenous or oral, or topical) necessitates additional observations, adding another group exposed to similar amount of intravenous mannitol or comparing two paracetamol formulations containing one containing mannitol, the other without mannitol: "mannitol may matter."

\section{Disclosure}

The author reports no conflicts of interest in this communication. 


\section{References}

1. Van den Heever D, Meyer D. The intraocular pressure-lowering properties of intravenous paracetamol. Clin Ophthalmol. 2016;10:1283-1289.

2. Chiam E, Weinberg L, Bellomo R. Paracetamol: a review with specific focus on the haemodynamic effects of intravenous administration. Heart Lung Vessel. 2015;7(2):121-132.
3. Mauger TF, Nye CN, Boyle KA. Intraocular pressure, anterior chamber depth and axial length following intravenous mannitol. JOcul Pharmacol Ther. 2000;16(6):591-594. 


\section{Authors' reply}

Henning van den Heever

David Meyer

Division of Ophthalmology, Faculty of Medicine and Health Sciences, Stellenbosch University, Cape Town, South Africa

Correspondence: Henning van den Heever

Division of Ophthalmology, Faculty of Medicine and Health Sciences, Stellenbosch University, PO Box 24I, Cape Town, 8000, South Africa

Tel +27219389380

$\mathrm{Fax}+27219385511$

Email henningjv@yahoo.com

\section{Dear editor}

We appreciate the comments received in response to our paper correctly highlighting the fact that not all intravenous paracetamol formulations contain the same excipients and that intravenous paracetamol has also manifested other unintended systemic side effects. An example of this is apparent systemic hypotension. ${ }^{1,2}$ Whether these unintended effects result from pharmacological (drug or excipients) or nonpharmacological (volume addition or excipients) factors is not yet clear. Further studies comparing different formulations of intravenous paracetamol will assist in quantifying the relative contribution of the following components of intravenous paracetamol to possible change in intraocular pressure (IOP): rapid addition of intravascular volume, paracetamol as a drug, and the excipients in the solution..$^{2-4}$

Given the known inconsistency of the dose-response curve of mannitol, purely theoretical prediction of any ocular hypotensive effect at the quantities contained in Perfalgan ${ }^{\text {B }}$ ( $3.85 \mathrm{~g}$ and $300 \mathrm{mOsmol} / \mathrm{kg}$ ) would probably not be helpful without clinical testing. ${ }^{5}$ This should form the primary objective in a follow-up study.

What we do know is that paracetamol has IOP-lowering properties and numerous papers show that paracetamol interacts with the endocannabinoid system. ${ }^{6-9}$ Unpublished data from our laboratory show that topical paracetamol has IOP-lowering properties in New Zealand White rabbits.
The aim of our study however was to attempt to answer the following question in clinical ophthalmology: Is there a change in IOP after intravenous administration of paracetamol (in our case, Perfalgan ${ }^{\circledR}$ )? Although an ocular hypotensive effect might support the endocannabinoid mechanism of action of paracetamol claimed by Högestätt et $\mathrm{al}^{9}$ and Ottani et $a l,{ }^{8}$ this was not the conclusion of our study. Our findings could only conclude that clinicians interpret IOP measurements taken within 6 hours after the administration of intravenous paracetamol with caution.

\section{Disclosure}

The authors report no conflicts of interest in this communication.

\section{References}

1. Van den Heever H, Meyer D. The intraocular pressure-lowering properties of intravenous paracetamol. Clin Ophthalmol. 2016;10:1283-1289.

2. Chiam E, Weinberg L, Bellomo R. Paracetamol: a review with specific focus on the haemodynamic effects of intravenous administration. Heart Lung Vessel. 2015;7(2):121-132.

3. Li JC, Gupta VK, You Y, Ng KW, Graham SL. The dynamic response of intraocular pressure and ocular pulse amplitude to acute hemodynamic changes in normal and glaucomatous eyes. Invest Ophthalmol Vis Sci. 2013;54(10):6960-6967.

4. Nongpiur ME, Foo VH, de Leon JM, et al. Evaluation of choroidal thickness, intraocular pressure, and serum osmolality after the water drinking test in eyes with primary angle closure. Invest Ophthalmol Vis Sci. 2015;56(4):2135-2143

5. Sorani MD, Manley GT. Dose-response relationship of mannitol and intracranial pressure: a meta-analysis. J Neurosurg. 2008;108(1): 80-87.

6. Mohamed N, Meyer D. Intraocular pressure-lowering effect of oral paracetamol and its in vitro corneal penetration properties. Clin Ophthalmol. 2013;7:219-227.

7. Vettor R, Pagotto U, Pagano C, Pasquali R. Here, there and everywhere: the endocannabinoid system. J Neuroendocrinol. 2008;20(Suppl 1): iv-vi.

8. Ottani A, Leone S, Sandrini M, Ferrari A, Bertolini A. The analgesic activity of paracetamol is prevented by the blockade of cannabinoid CB 1 receptors. Eur J Pharmacol. 2006;531(1):280-281.

9. Högestätt ED, Jönsson BA, Ermund A, et al. Conversion of acetaminophen to the bioactive N-acylphenolamine AM404 via fatty acid amide hydrolase-dependent arachidonic acid conjugation in the nervous system. J Biol Chem. 2005;280(36):31405-31412.

Dove Medical Press encourages responsible, free and frank academic debate. The content of the Clinical Ophthalmology 'letters to the editor' section does not necessarily represent the views of Dove Medical Press, its officers, agents, employees, related entities or the Clinical Ophthalmology editors. While all reasonable steps have been taken to confirm the content of each letter, Dove Medical Press accepts no liability in respect of the content of any letter, nor is it responsible for the content and accuracy of any letter to the editor.

Clinical Ophthalmology

Dovepress

\section{Publish your work in this journal}

Clinical Ophthalmology is an international, peer-reviewed journal covering all subspecialties within ophthalmology. Key topics include: Optometry; Visual science; Pharmacology and drug therapy in eye diseases; Basic Sciences; Primary and Secondary eye care; Patient Safety and Quality of Care Improvements. This journal is indexed on

Submit your manuscript here: http://www.dovepress.com/clinical-ophthalmology-journal
PubMed Central and CAS, and is the official journal of The Society of Clinical Ophthalmology (SCO). The manuscript management system is completely online and includes a very quick and fair peer-review system, which is all easy to use. Visit http://www.dovepress.com/ testimonials.php to read real quotes from published authors. 